\title{
Assessment of Genetic Divergence in Ashwaganda [Withania somnifera (L.) Dunal]
}

\author{
Kapil Kumar Nagar*, R. B. Dubey, Turfan Khan, H. K. Tank and L. L. Bairwa \\ Department of Genetics and Plant Breeding, Rajasthan College of Agriculture, Maharana \\ Pratap University of Agriculture \& Technology, Udaipur (Rajasthan)-313001, India
}

*Corresponding author

\section{A B S T R A C T}

Keywords

D2 statistics, Genetic divergence, Cluster, Cluster composition

\section{Article Info}

\section{Accepted:}

08 January 2020

Available Online:

10 February 2020
Sixty ashwagandha germplasm and 3 checks were evaluated to study the diversity pattern among the collected accession. The genotypes were grouped into eight clusters. The cluster VII had highest number of genotypes (18) followed by (10) in cluster III. The inter-cluster distance was higher than intra cluster distance indicating wide genetic diversity among the genotypes. The highest intra cluster distance was in cluster-III followed by IV, II and I. The four clusters (V, VI, VII and VIII) contained single genotype each and therefore, their intra-cluster distances were zero. The average inter cluster values were maximum between cluster II and VII followed by cluster VII and VIII showed wider diversity among the groups.

\section{Introduction}

Ashwagandha [Withania somnifera (L.) Dunal] also known as Indian ginseng (poison) gooseberry or winter cherry is a plant of the solanaceae family (Mir et al., 2013) with chromosome $2 \mathrm{n}=48$ is native of north-western region and central India as well as Mediterranean region of north Africa. In India two species of genus Withania viz., Withania somnifera (L.) Dunal (ashwagandha) Withania coagulans (L.) Dunal (panir) are found. It is an interest to record that the cultivated plants have sizable differences from the wild plants not only in their morphological characters including low branching but also in their therapeutical action. Withania somnifera (L.) is an erect evergreen, $60-70 \mathrm{~cm}$ tall, under domestication and it is grown for its roots, leaves are simple ovate and opposite. The flowers are inconspicuous greenish or dull yellow and bisexual. Withania coagulans is rigid grey under shrub of $60-120 \mathrm{~cm}$ height. The fruit is called berry and orange/red in colour when mature. The seeds are small flat yellow and 
uniform in shape and very light in weight (Atal et al., 1961). The main alkaloids are withanolids, sominiferine, sominiferinine, somnine, withananine, pseudo withananinine, and asomnine (Covello and Ciampa, 1960). It is also an in gradient of medicaments prescribed for curing disability and sexual weakness in males. Seeds are diuretic, warm leaves are used for providing comfort during eye disease (Nigam and Kandalkar, 2006).

\section{Materials and Methods}

The Experiment was laid out late kharif-2017 in the Botany farm at Rajasthan college of Agriculture, Maharana Pratap University of Agriculture and Technology, Udaipur to assess genetic divergence among sixty three genotypes with three standard check (JA-20, JA-134 and RVA-100) by growing them in a Randomized Block Design (RBD) with three replications a single row plot of 4.0 meter length maintaining a crop geometry of $30 \times 5$ $\mathrm{cm}$.

\section{Results and Discussion}

\section{Genetic divergence}

Genetic diversity present in available genotypes plays an important role in crop improvement for characters of interest. For the selection of parents in hybridization, diversity among parents for the character of interest, estimation of genetic distance is most important.

The concept of $\mathrm{D}^{2}$ technique was originally developed by P. C. Mahalanobis in 1928 but the application of this technique for the assessment of genetic diversity in plant breeding was suggested by Rao (1952). Higher the genetic diversity between the parents, greater is the chance of achieving transgressive segregants. $\mathrm{D}^{2}$ statistics is a potential tool for obtaining quantitative estimates of divergence between biological populations and has extensively been applied to assess diversity. $\mathrm{D}^{2}$ gives clear idea about diverse nature of the population.

\section{Multivariate analysis of variance}

$\mathrm{D}^{2}$ analysis was carried out using fifteen characters viz., days of flowering, days to 75 per cent maturity, plant height, number of primary branches per plant, number of secondary branches per plant, leaf area index, root length, root diameter at collar region, fresh root yield per plant, dry root yield per plant, dry plant weight per plant, fresh plant weight per plant, 100 seed weight, harvest index and total alkaloid content having significant difference between genotype and independency for observation.

A multivariate analysis of variance indicates that there was significant difference between genotypes over the characters.

\section{Grouping of genotypes into various clusters}

The sixty three genotypes were grouped in 8 clusters. The number of genotypes in each cluster ranged from 2 to 18 .

Clustering of genotypes under study is presented in Table 1 and all the genotypes were grouped into eight clusters, indicating the presence of diversity for different characters. The cluster VII had highest number of genotypes (18) followed by 10 in cluster III, 9 in cluster IV, 8 in cluster V, 7 in cluster VI,5 in cluster I, 4 in cluster II and 2 in cluster VIII. The similar results were also reported by Joshi et al., (2015). The clustering pattern revealed that, in general, genotypes from same origin showed no tendency to be in same cluster.

Looking to the pattern of genotypes distribution into different clusters in the 
present study, it appeared that geographical distance between the genotypes had no relation with the genetic divergence as the genotypes from same source had fallen into different clusters as well as the same cluster contained genotypes from different sources.

\section{Intra and inter clusters distance}

The average intra and inter cluster distance are given in table 2. Maximum intra cluster distance was in cluster-III (42.22) followed by IV (40.76), II (35.50), I (35.48). There were no intra-cluster distance in some clusters like V, VI, VII and VIII. The high intra-cluster distance in cluster III indicated the presence of wide genetic diversity among the genotypes in this cluster.

The average inter cluster values were maximum between cluster II and VII followed by cluster VII and VIII and cluster I and cluster VII and cluster VI and cluster VII. The similar results were also reported by Joshi et al., (2015).

\section{Relative contribution of different characters}

Relative contribution of each of the 15 characters towards the total divergence was worked out using per cent I rank and some $\mathrm{D}^{2}$ for each character over the pairs of genotype (table.3). Trend of contribution of different characters was same in both the methods. Maximum contribution towards the total $\mathrm{D}^{2}$ using square of $\mathrm{D}^{2}$ was found to be from total alkaloid content $(61.60 \%)$ followed by dry plant weight per plant $(16.44 \%)$, leaf area index $(8.76 \%)$, harvest index $(6.50 \%)$, dry root yield $(1.18 \%)$, fresh plant weight (1.08 $\%$ ), fresh root yield and number of primary branch $(0.87 \%), 100$ seed weight $(0.82 \%)$, root diameter in collar region $(0.61 \%)$, number of secondary branch/plant $(0.51 \%)$, plant height $(0.36 \%)$, root length $(0.31 \%)$, days to flowering $(0.10 \%)$ and the at least or zero contribution was from days to 75 per cent maturity.

Table.1 Cluster composition

\begin{tabular}{|c|c|c|}
\hline Cluster & $\begin{array}{l}\text { Number of } \\
\text { genotypes }\end{array}$ & Genotype \\
\hline $\mathbf{I}$ & 5 & MPAS-5, MPAS-8, MPAS-10, MPAS-24, MPAS-56 \\
\hline II & 4 & MPAS-2, MPAS-26, MPAS-55, MPAS-58 \\
\hline III & 10 & $\begin{array}{l}\text { MPAS-7, MPAS-17, MPAS-21, MPAS-23, MPAS-37, MPAS- } \\
\text { 53, MPAS-54, MPAS-59, JA-34, RVA-100 }\end{array}$ \\
\hline IV & 9 & $\begin{array}{l}\text { MPAS-1, MPAS-22, MPAS-28, MPAS-30, MPAS-40, MPAS- } \\
\text { 41, MPAS-43 MPAS-47, MPAS-51 }\end{array}$ \\
\hline $\mathbf{V}$ & 8 & $\begin{array}{l}\text { MPAS-6, MPAS-19, MPAS-25, MPAS-34, MPAS-36, MPAS- } \\
\text { 38, MPAS-45, MPAS-46 }\end{array}$ \\
\hline VI & 7 & $\begin{array}{l}\text { MPAS-11, MPAS-14, MPAS-18, MPAS-20, MPAS-42, MPAS- } \\
\text { 48, MPAS-57 }\end{array}$ \\
\hline VII & 18 & $\begin{array}{l}\text { MPAS-3, MPAS-4, MPAS-12, MPAS-13, MPAS-16, MPAS-27, } \\
\text { MPAS-29, MPAS-31, MPAS-32, MPAS-33, MPAS-35, MPAS- } \\
\text { 39, MPAS-44, MPAS-49, MPAS-50, MPAS-52, MPAS-60, JA- } \\
134\end{array}$ \\
\hline VIII & 2 & MPAS-9, MPAS-15 \\
\hline
\end{tabular}


Table.2 Average intra and inter cluster $\mathrm{D}^{2}$ values in 63 genotypes of ashwagandha

\begin{tabular}{|l|c|c|c|c|c|c|c|c|}
\hline & Cluster-I & Cluster-II & Cluster-III & Cluster-IV & Cluster-V & Cluster-VI & Cluster-VII & Cluster-VIII \\
\hline Cluster-I & $\mathbf{3 5 . 4 8 6}$ & 74.119 & 95.393 & 83.373 & 47.912 & 52.597 & 172.155 & 68.065 \\
\hline Cluster-II & & $\mathbf{3 5 . 5 0 6}$ & 89.750 & 200.674 & 105.282 & 127.938 & 308.681 & 129.736 \\
\hline Cluster-III & & & $\mathbf{4 2 . 2 2 4}$ & 145.514 & 77.427 & 131.481 & 162.187 & 133.273 \\
\hline Cluster-IV & & & & $\mathbf{4 0 . 7 6 8}$ & 56.910 & 71.239 & 75.206 & 96.493 \\
\hline Cluster-V & & & & & $\mathbf{0 . 0 0 0}$ & 72.136 & 111.466 & 62.329 \\
\hline Cluster-VI & & & & & & $\mathbf{0 . 0 0 0}$ & 133.778 & 39.893 \\
\hline Cluster-VII & & & & & & & $\mathbf{0 . 0 0 0}$ & 188.625 \\
\hline Cluster-VIII & & & & & & & & $\mathbf{0 . 0 0 0}$ \\
\hline
\end{tabular}

Table.3 Relative contribution of different characters

\begin{tabular}{|l|c|c|}
\hline \multicolumn{1}{|c|}{ Source } & Times Ranked 1 $^{\text {st }}$ & Contribution \% $^{\text {\% }}$ \\
\hline 1 Days to Flowering & 2.000 & 0.10 \\
\hline 2 Day to 75\% Maturity & 0.000 & 0.01 \\
\hline 3 Plant Height (cm) & 7.000 & 0.36 \\
\hline 4 Number Of Primary Branches/ Plant & 17.000 & 0.87 \\
\hline 5 Number Of Secondary Branches/ & 10.000 & 0.51 \\
\hline Plant & & \\
\hline 6 Root Length (cm) & 6.000 & 0.31 \\
\hline 7 Fresh Root Yield g/Plant & 17.000 & 0.87 \\
\hline 8 Root Diameter In Collar Region & 12.000 & 0.61 \\
\hline 9 Dry Plant Weight per plant & 321.000 & 16.44 \\
\hline 10 Fresh Plant Weight & 21.000 & 1.08 \\
\hline 11 Harvest Index (\%) & 127.000 & 6.50 \\
\hline 12 Leaf Area Index & 171.000 & 8.76 \\
\hline 13 Total Alkaloid content & 1203.000 & 61.60 \\
\hline 14 100 Seed Weight & 16.000 & 0.82 \\
\hline 15 Dry Root Yield & 23.000 & 1.18 \\
\hline
\end{tabular}


Table.4 Cluster mean for fifteen characters in ashwagandha

\begin{tabular}{|c|c|c|c|c|c|c|c|c|c|c|c|c|c|c|c|}
\hline Character & $\begin{array}{c}\text { Day to } \\
\text { Flowering }\end{array}$ & $\begin{array}{c}\text { Day to } \\
75 \% \\
\text { Maturity }\end{array}$ & $\begin{array}{c}\text { Plant } \\
\text { Height } \\
\text { (cm) }\end{array}$ & $\begin{array}{c}\text { Number } \\
\text { of } \\
\text { Primary } \\
\text { Branches/ } \\
\text { Plant }\end{array}$ & $\begin{array}{c}\text { Number of } \\
\text { Secondary } \\
\text { Branches/ } \\
\text { Plant }\end{array}$ & $\begin{array}{c}\text { Root } \\
\text { Length } \\
(\mathbf{c m})\end{array}$ & $\begin{array}{c}\text { Fresh } \\
\text { Root } \\
\text { Yield } \\
\text { g/Plant }\end{array}$ & $\begin{array}{c}\text { Root } \\
\text { Diameter } \\
\text { In Collar } \\
\text { Region }\end{array}$ & $\begin{array}{c}\text { Dry } \\
\text { plant } \\
\text { weight } \\
\text { / plant }\end{array}$ & $\begin{array}{c}\text { Fresh } \\
\text { plant } \\
\text { weight/p } \\
\text { lant }\end{array}$ & $\begin{array}{l}\text { Harves } \\
\text { t index }\end{array}$ & $\begin{array}{c}\text { Leaf } \\
\text { area } \\
\text { index }\end{array}$ & $\begin{array}{c}\text { Total } \\
\text { alkaloid } \\
\text { content }\end{array}$ & $\begin{array}{c}100 \text { seed } \\
\text { Weight }\end{array}$ & $\begin{array}{l}\text { Dry root } \\
\text { yield/plant }\end{array}$ \\
\hline Cluster-I & 101.765 & 170.358 & 39.389 & 4.969 & 9.645 & 20.563 & 13.507 & 8.841 & 28.824 & 93.312 & 9.504 & 0.940 & 0.393 & 0.211 & 2.614 \\
\hline Cluster II & 99.926 & 169.481 & 40.354 & 5.041 & 9.426 & 20.048 & 12.621 & 8.319 & 34.167 & 110.363 & 7.901 & 0.940 & 0.470 & 0.212 & 2.529 \\
\hline Cluster III & 100.583 & 169.583 & 36.235 & 5.125 & 9.450 & 19.492 & 14.114 & 9.242 & 55.292 & 165.402 & 4.048 & 0.927 & 0.428 & 0.199 & 2.238 \\
\hline Cluster IV & 100.526 & 170.930 & 38.059 & 4.806 & 9.435 & 20.716 & 13.699 & 8.791 & 34.482 & 114.609 & 8.335 & 0.931 & 0.314 & 0.206 & 2.645 \\
\hline Cluster V & 99.000 & 165.000 & 36.733 & 5.833 & 10.533 & 18.400 & 12.667 & 7.300 & 41.987 & 126.877 & 8.863 & 0.857 & 0.372 & 0.181 & 3.713 \\
\hline Cluster VI & 101.000 & 170.000 & 39.667 & 5.067 & 9.170 & 19.000 & 16.500 & 7.567 & 19.640 & 109.070 & 18.923 & 1.023 & 0.356 & 0.194 & 3.720 \\
\hline Cluster VII & 103.667 & 170.333 & 36.567 & 5.193 & 10.667 & 18.367 & 11.633 & 9.300 & 59.080 & 166.253 & 6.253 & 1.010 & 0.291 & 0.202 & 3.677 \\
\hline Cluster VIII & 100.000 & 165.333 & 44.167 & 5.100 & 7.867 & 21.333 & 19.303 & 8.167 & 20.417 & 74.113 & 24.167 & 0.873 & 0.370 & 0.185 & 4.917 \\
\hline
\end{tabular}




\section{Cluster means}

The cluster means (Table 1.5) indicated that cluster VIII was having maximum dry root yield per plant (4.91), harvest index (24.16), fresh root yield per plant (19.03), root length (21.33) and plant height (44.16), cluster VII having maximum fresh plant weight (166.25), dry plant weight (59.08), number of secondary branch per plant (10.66) and root diameter in collar region (9.30), cluster $\mathrm{V}$ shows earliest days to flowering (99), earliest day to 75 per cent maturity (165) and number of primary branch per plant (5.83), cluster VI shows maximum leaf area index (1.023) and cluster II having maximum total alkaloid content (0.47) and 100-seed weight (0.212) therefore selection of genotypes for these characters may be made from these clusters.

\section{References}

Allard, R.W. 1960. Principal of Plant Breeding. John Wiley and Sons, Inc. New York.

Atal, C.K. and Schwarting, A.E. 1961.
Ashwagandha - An ancient Indian Drugs. Economic Botany, IS:256-263.

Joshi, N.R., Patel, M.A., Prajapati, K.N., Patel, J.R. and Patel, A.D.2015. Genetic diversity in Ashwagandha (Withania somnifera (L.) Dunal). Electronic Journal of Plant Breeding, 6: 870-874.

Kandalkar, V.S., Patidar, H. and Nigam, K.B. 1993. Genotypic association and path coefficient analysis in ashwagandha (Withania somnifera). The Indian Journal of Genetics and Plant Breeding, $53: 257-260$.

Mahalanobis, P.C. 1936. On the generalized distance in statistics. Proceedings of National Academic Science (India). 2: 79-85.

Mir, B.A., Koul, S., Soodan, A.S. 2013. Reproductive biology of Withania ashwagandha sp. novo (Solanaceae). Industrial Crops and Products, 45: 442-446.

Rao, C. R. 1952. Advanced statistical Methods in Biometrical Research. John Wiley and Sons. Inc., New York: 390.

\section{How to cite this article:}

Kapil Kumar Nagar, R. B. Dubey, Turfan Khan, H. K. Tank and Bairwa, L. L. 2020. Assessment of Genetic Divergence in Ashwaganda [Withania somnifera (L.) Dunal]. Int.J.Curr.Microbiol.App.Sci. 9(02): 1789-1794. doi: https://doi.org/10.20546/ijcmas.2020.902.204 